\title{
Degenurted
}

G

DOI: $10.1515 / \mathrm{abcsj}-2016-0020$

\section{Creative Pluralism in Indian and Romanian Accounts of Transnational Migration}

\author{
ADRIANA ELENA STOICAN \\ Lumina, The University of South East Europe
}

\begin{abstract}
The paper offers a comparative perspective on transmigrant cultural identities as illustrated in the works of two contemporary South Asian American and Romanian American authors, Jhumpa Lahiri and Aura Imbăruș. The comparison involves Gogol, a South Asian American character, and Aura, the author of the memoir Out of the Transylvania Night. Although Gogol is a fictional character and Aura is an actual transmigrant, their comparative assessment relies on the assumption that both narratives are inspired by the authors' background of relocation. Despite their different cultural origins, both authors share thematic aspects related to the dynamics of cultural identity in the context of migration. This paper aims to provide a starting point for an enlarged framework of comparative analysis, in order to foreground intersections between different experiences of cultural negotiation in the context of displacement. Born and raised in America, Gogol is challenged by his cultural multiplicity and strives to suppress elements of his Indian identity. After years of rebelling against his parents' norms, Gogol shifts to the Bengali model, when his father dies. Once he accepts the relevance of his cultural roots, Gogol is able to plunge into a dimension situated beyond his Bengali and American selves. His transcendent strategy is illustrated by his decision to plunge into a third space of redefinition, suggested by the Russian literature which is appreciated by Gogol's father. Aura Imbăruș offers the example of a first generation Romanian transmigrant who undergoes voluntary relocation to the United States. Fascinated by the American world, Aura is eager to take over norms of material success and consumerism, overlooking the relevance of her cultural roots. When she undergoes a personal family crisis, Aura eventually reassesses the value of her Romanian background, aiming to reconcile her source culture with her Americanised self. In a manner similar to Gogol's, Aura manages to integrate American norms of success,
\end{abstract}


while forging enduring bonds with the Romanian American community in California.

Keywords: Americanisation, borders, cultural pluralism, incompleteness, networks, relocation, transcendent, transcultural, transnational, transmigrant

\section{Introduction}

The paper aims to investigate the cultural evolution of South Asian American and Romanian transmigrants, as illustrated by contemporary accounts of displacement, mirrored in fictional as well as autobiographic writings. The discussion compares Gogol, a second generation character from Jhumpa Lahiri's novel, The Namesake, with Aura Imbăruş, the Romanian author and protagonist of the memoir Out of the Transylvania Night.

An important trigger of this comparative analysis is my personal bond with the Romanian, Indian and North American cultural spaces. First, my academic expertise formed in Bucharest involves a double specialisation in English and Hindi philology. This educational training has deepened my knowledge of the English, American and Indian cultural traditions. Second, my professional background is coupled with my personal experiences of student migration to India and Canada. I am certain that my relocation to the Indian and North American spaces contributes to a comprehensive interpretation of contemporary cultural identities shaped by migration.

Although the two works belong to different literary genres, my intention to compare them is justified by the fact that these creations are inspired by the authors' background of transnational migration. I will employ the syntagm 'accounts of uprooting' so as to foreground the themes of migration and culture as the main grids of interpreting the primary corpus. By comparing experiences of displacement undergone by individuals from different cultural traditions, this paper aims to retrieve common mechanisms of processing otherness that become activated irrespective of one's cultural affiliation. By revealing intersecting 
strategies of dealing with cultural diversity, the discussion sets out to suggest the possibility of a comparative framework for filtering alterity.

\section{Authors' Background}

Jhumpa Lahiri was born to Bengali immigrant parents in London and grew up in New England, the USA. As with most of her secondgeneration characters, she performed temporary relocations to India (Calcutta) in her youth. Jhumpa Lahiri experienced a great deal of confusion with respect to her cultural identity in adolescence. The author considers that she has inherited a sense of longing and loss from her parents, whose generation seems indefinitely trapped in an emotional exile (Lahiri to Farnsworth 2000; Lahiri to R. Shankar 1999). The Namesake presents the evolution of a Bengali immigrant couple (Ashoke and Ashima Ganguli) and the different strategies adopted by them and their son Gogol in navigating multiple traditions.

Aura Imbăruş was born and raised in Sibiu/ Hermannstadt, Romania, where she attended Lucian Blaga University. In 1997, she won the American visa lottery and left for the United States, eventually settling in California with her Romanian husband, Michael. At present, she is a high school teacher of philosophy, American literature and human sciences in Los Angeles. Besides her educational career, Aura is a praised writer. Her first book, Out of the Transylvania Night (2010), was considered for being shortlisted for the Pulitzer Prize (Unica 2013). The first two parts of the book present Aura's memories of her life in communist and postcommunist Romania. The third section describes her settlement in America, foregrounding her multiple relocations between Romania and America.

\section{Theoretical Considerations}

In order to account for Gogol's and Aura's cultural metamorphoses, the paper relies on theoretical notions regarding transnational processes and transcultural mechanisms of identity negotiation. Transnationalism is associated with an intersection of cultural patterns, described by various 
terms (creolisation, syncretism, bricolage, cultural translation, hybridity) and analyzed in relation to global media and communication (Vertovec 56). From an anthropological perspective, transnationalism denotes "processes by which immigrants forge and sustain multi-stranded social relations that link together their societies of origin and settlement" (Basch et al. 7). This theoretical approach redefines immigrants as transmigrants, i.e. immigrants who build social fields that cross geographic, cultural and political borders by their engagement in networks of relationships that connect them to two or more nation states simultaneously (Basch et al. 7). This concept is meant to transcend the connotations of uprootedness inherent in immigrant dislocation. At the same time, it also aims to discard the idea of temporary residence, associated with the migrant condition (Basch et al. 4). Considering that Gogol and Aura are involved in repeated episodes of travel between India/ Romania and America, the present discussion refers to them as transmigrants, foregrounding their participation in transnational networks.

Considering that transnational mobility implies one's contact with multiple cultural spaces, the transcultural discourse serves as a useful theoretical tool for assessing the characters' capacity to process cultural multiplicity. The idea of cultures as self-transcendent entities is an important principle of transculturality, foregrounding the necessity to acknowledge the relevance of different cultural worlds. The transcultural approach suggests that cultural intersections involve an engagement with "differences inherent in other cultures, especially as these differences speak to gaps within the knowledge/experience base of one's own culture" (Berry 130, my emphasis). The idea of intrinsic cultural incompleteness is an important trigger of transcultural perceptions. More specifically, the acknowledgement of missing elements from one's set of cultural values shapes the individuals' need to step out of their cultural sphere and adopt different cultural practices: "Perhaps the most effective way to feel difference is to embrace the feeling of one's own incompleteness" (Epstein, After the Future 302). This notion implies the transcendence of singular, bounded or hybridized identity models into a realm situated on the border of all cultures, which is conceptualized as transculture (Epstein, Transcultural Experiments 24). Cultures as open systems stand for the 
main premise of transcultural dialogues, which are made possible by the permeability of cultural borders. Starting from these premises, this paper investigates Gogol's and Aura's intuitions of a lack within their native cultural backgrounds that makes them aware of the potential of other cultures to enrich their own traditions. The transcultural approach envisages the achievement of cultural syntheses in terms of creative pluralism, a result of the intuition that each culture can contribute to the enrichment of others:

Transcultural pursuits should aim to understand and overcome the limitations of one's inborn culture ... I would name such a project 'creative pluralism' because it does not limit itself to the simple recognition of other cultures' integrity, but goes so far as to consider them all necessary for each other's further development. (Epstein, After the Future 303)

Along with the idea of respect for cultural difference, creative pluralism also involves its incorporation that ultimately enriches one's cultural background. This approach dismantles a separatist outlook on cultures, facilitating the occurrence of cultural transfers. Thurlow Crispin associates transculturalism with the dynamic nature of cultures, defining them as fluctuating structures. She considers that the term 'transcultural' captures the unpredictable nature of cultural contacts, by denoting "a sense of moving through and across cultural systems..." (n.d., n.p.; emphasis in the original). The transcultural connotation of mobility and change can be linked with the transmigrants' potential to create new cultural identities in the context of their accelerated mobility. Assuming a connection between transnational contexts and transcultural exchanges, Hannerz considers that the transnational ties of contemporary cultures create a sense of global interconnectedness, conceptualized as "global ecumene" (7). Defining cultural diversity as one of the "transnational commons" within the global ecumene, he advances the possibility of "creative confrontations" (Hannerz 61). The transnational connections thus defined configure the contemporary global ecumene as an open landscape in terms of social relationships and flows of culture. This transnational cultural repertoire of alternatives to bounded cultural systems shares the transgressive connotations of the transcultural 
paradigm. Hence, virtually every individual placed in the global ecumene is free to associate and insert different cultural practices into his/her profile.

These theoretical considerations suggest that the transcultural and transnational fields intersect, given their common emphasis on boundary transgression. While the transcultural outlook focuses on cultural transformation, transnationalism denotes a regime of intensified mobility that facilitates one's contact with different cultural backgrounds. Taking into account the dynamic nature of cultures and their transcendent mechanisms, along with the permeable structure of cultural borders, the following section analyses the evolution of two transmigrants who become transcultural by integrating cultural difference into their specific backgrounds.

\section{Creative Pluralism: A Comparative Perspective}

The condition of transnationality is an important point of intersection between the two narratives of displacement, although it is experienced differently by Gogol and Aura. The Bengali character's transmigrant profile is configured by his family's periodic visits to India during his childhood and teenage years. By comparison, Aura Imbăruș' itinerary of migration is more intensely transnational, as she maintains stronger networks of communication with Romania, by both physical and communicative travel (Larsen et al. 5). Considering this overlap in Gogol's and Aura's transmigrant conditions, the paper aims to demonstrate that despite their different cultural origins, they develop analogous mechanisms of cultural redefinition. More specifically, both characters seem haunted by a feeling of cultural lack meant to be filled by elements from foreign cultures. Both of them manifest the urge to repress their native traditions and refashion themselves along (predominantly) American lines. Eventually, both Gogol and Aura understand the relevance of their source culture and acknowledge its validity as a meaningful component of their identities. Their similar strategies of identity negotiation foreground their transcultural awareness that helps them transgress cultural barriers and turn their cultural plurality into a 
coherent self. Aura's and Gogol's integration of cultural difference within their source cultures suggests that the cultural logic of identity in the global context may require culture transcendent coordinates that facilitate dialogues across cultural borders.

\section{Gogol Ganguli: a Bengali-American synthesis}

This discussion suggests that Gogol's transcultural understanding is the outcome of a long oscillation between his Bengali inheritance and his selfidentification as an American. Gogol's strategy of dealing with his cultural plurality is expressed by his consistent effort to deny Bengali cultural elements, followed by his attempt to suddenly accept them.

Gogol's initial rejection of his parents' cultural norms is suggested by his fraught relationship with his pet name, Gogol, that reflects Ashoke's preference for Russian literature. Gogol's deviation from his family tradition starts in his childhood when he decides to turn his pet name (Gogol), reserved for the private sphere according to Bengali customs into a good name, which is traditionally associated with the public life of an individual. He refuses to be called Nikhil at kindergarten, deviating from the Bengali manner of employing the good name (Nikhil) in public. Later on, the character understands that his pet name (used as a good name) sets him apart in the American context. Since the name Gogol initially marks the character's impossibility to feel included in the American space, Gogol considers his other name - Nikhil - as conducive to stronger acceptance by his American colleagues. Gogol's decision to

change his name from Gogol to Nikhil when he turns eighteen is part of his strategy to define himself as an American teenager, since the possibility of renaming oneself is "a right belonging to every American citizen" (Lahiri 99).

However, after his father's sudden death, Gogol reconsiders his choices, attempting to retrieve his parents' cultural meanings. As he strives to reconnect with his roots, Gogol realises that a complete return to sameness is no longer possible, as suggested by his unsuccessful marriage to Moushoumi, a second generation South Asian American like himself. After failed connections with non-Indian partners, Gogol and Moushoumi 
start their relationship hoping to find solace in the comfort of their similar backgrounds. However, this bond does not last, since Moushoumi feels eventually trapped in a marriage that does not fulfil her sophisticated cultural tastes (Stoican 247). In the long run, Gogol acquires a personal understanding of how he can redefine himself by reconciling his Bengali coordinates with American ideals. More specifically, Gogol realises that a more satisfying approach to self-redefinition involves a personal ability to integrate elements of sameness and difference without privileging a particular culture. Gogol's path to self-discovery advances the idea that the story of identity is complicated by one's relocation, since mobility across physical boundaries also involves unexpected crossings of cultural borders:

\begin{abstract}
In so many ways, his family's life feels like a string of accidents, ... It had started with his father's train wreck, paralyzing him at first, later inspiring him to make a new life on the other side of the world. There was the disappearance of the name Gogol's great-grandmother had chosen for him, lost in the mail somewhere between Calcutta and Cambridge. This had led, in turn, to the accident of his being named Gogol, defining and distressing him for so many years. He had tried to correct that randomness, that error. And yet it had not been possible to reinvent himself fully, to break from that mismatched name. His marriage had been something of a misstep, as well... (Lahiri287)
\end{abstract}

The contingent nature of Gangulis' evolution is related to their family history, rendered discontinuous by migration. I interpret the idea of accidents in relation with identity formation as an indicator of the fact that there are no precise rules that govern the process of cultural interaction. Gogol realises that he has tried to organise his cultural multiplicity by applying symmetric principles: the alternative adoption of cultural difference and sameness. Upon realising that his strategy has not created a balanced cultural self, Gogol understands that he has to harmonise his plurality by a different approach for which he has formulated no definition. While Friedman considers that Gogol's remarks make up a sum of "banal, touristy observations" (123), I think they reveal his deeper understanding of the events that have influenced his destiny. Therefore, my argument aligns with Caesar's conclusion regarding Gogol's achieved maturity: "He seems changed, more complex, more aware of the 
contradictions of his life and more accepting of them" (118). Another dimension of Gogol's understanding is the necessity to construct a permanent dialogue between himself and the circumstances of his past. I consider one step of Gogol's transcultural vision to be a willingness to accept his native background as a possible source for self- redefinition. As he becomes more mature, Gogol acknowledges the importance of Bengali cultural forces in the dynamics of his cultural identity:

And yet these events have formed Gogol, shaped him, determined who he is. They were things for which it was impossible to prepare but which one spent a lifetime looking back at, trying to accept, interpret, comprehend. Things that should never have happened, that seemed out of place and wrong, these were what prevailed, what endured in the end. (Lahiri 287, my emphasis)

The processes of acceptance, interpretation and comprehension indicate the permanent negotiation of Gogol's multiple dimensions of his cultural self. In order to balance the various traditions that have shaped him, Gogol has to select the elements of a future synthesis.

\section{Going beyond Bengali Roots and American Norms}

In this context, I interpret his childhood exploration of Cape Cod under his father's guidance as a parallel between the first and second generation approach to relocation and cultural transformation. This episode refers to a Sunday afternoon when his family drove to the ocean. While Ashima and Gogol's sister (Sonia) waited on the shore, Ashoke and his son took a long walk along the breakwater, inspecting the entire area until they reached its margins. The father's impulse to explore the dam may echo his youthful determination to traverse different cultures. While the father leads the way, young Gogol literally steps into his footprints, suggesting his duty to continue the first generation's plunge into unknown territories. As they reach the margins of the dam, Ashoke asks Gogol to remember this location as "a place where there was nowhere left to go" (Lahiri 187). I suggest that Ashoke's perception of an ultimate boundary refers to his own sense of accomplishment as an immigrant, since his escape to America as a youth marks the last stage of his transition across cultures. 
Ashoke's achievement in the USA has been recorded by Song who considers him "at peace with the decisions he has made and the life he has chosen" (362). Since Ashoke has reached the end of his journeys through arrival in America, the ultimate frontier he signals to Gogol refers to the son's future challenge to continue what the father started through migration. Caesar interprets this scene as an expression of Ashoke's desire to teach Gogol the "courage to explore for oneself" (114) and to "deliver the message that the act of seeking is part of who one is" (114). Taking this argument further, I consider that Gogol's redefinition involves his seeking between cultural options, fusing different cultural elements and transgressing the very idea of separate cultures. In order to continue Ashoke's journey, Gogol has to move beyond the condition of a successful Bengali immigrant, and therefore achieve a sense of identity that transcends his Bengali and American coordinates. Gogol's career as an architect may be interpreted as an illustration of his urge to shape a transcultural identity, since both projects involve the creation of a complete structure based on the interconnection of different elements: "he knows that each component of a building, however small, is nevertheless essential" (Lahiri 125). In this respect, the family's involvement in patterns of transnational relocation to India appears to be an important coordinate that contributes to Gogol's transcultural redefinition. As well as Aura's trips to Romania, Gogol's travels to India help him achieve a sense of connection with his ancestors' traditions. Although India is foreign to Gogol in a way that Romania is not to Aura, his contact with Indian cultural emblems bonds the character with his Indian cultural core in unexpected ways. For example, during one of his trips to India, Gogol is fascinated by the architecture of the Taj Mahal realizing that "no other building has affected him so powerfully" (Lahiri 85). The family's visit to this architectural emblem marks Gogol's opening to his Indian background, since he takes up the study of Mughal architecture while back to the USA. Moreover, his senior thesis project illustrates the character's attempt to reconcile different cultural traditions, since it involves a comparison between Renaissance and Mughal architecture (Lahiri 120).

The transcultural awareness Gogol achieves after Ashoke's death 
helps him realise that he cannot keep emulating American models while discarding his parents' values. As a young man, Gogol's father was fascinated by the world of Russian literature, especially Nikolai Gogol, which suggests Ashoke's willingness to explore different cultures, subsequently taken over by his son. Similarly, Aura's family background displays patterns of cultural transgression that will be reflected in Aura's capacity to develop a transcultural self. According to Caesar, Ashoke's understanding of Nikolai Gogol's "The Overcoat" is useful in highlighting the transcultural dimension of Gogol's redefinition. The work of Nikolai Gogol connects Ashoke with his grandfather, who told him to read the Russian realists. This implies that Ashoke has reached a transcultural understanding before his son, given his transgression of several cultural traditions (Caesar 106). On Gogol's fourteenth birthday, Ashoke offers him Nikolai Gogol's book, but his son does not read it until after Ashoke's death. While a gesture of reconnection with his father's outlook is shown with Gogol's decision to read "The Overcoat," this also stands for a transgression of the two directions that have influenced his evolution (Bengali and American). This transcendence of two cultural traditions does not imply Gogol's immersion into the Russian culture as such, but the adoption of a perspective that privileges neither of the cultural traditions that shape his identity. In this context, Gogol's decision to travel alone (to Venice) after his divorce aligns with his effort to redefine himself by incorporating his past and also enriching it: "In the spring he went to Venice for a week ... saturating himself in its ancient, melancholy beauty" (Lahiri 283). Travelling to Europe is meant to correct the closed tradition of his family, who have never travelled to other countries apart from America and India. At the same time, Gogol's eagerness to explore different cultures foregrounds the importance of transnational mobility in the process of transcultural redefinition.

\section{Aura Imbăruș: Americanisation with a Twist}

Aura Imbăruş' experience of transnational migration illustrates her transcultural transformation by means of cultural fusion. By comparison with Gogol, the Romanian transmigrant is more mobile, a fact that can be 
correlated with the faster rhythm of her cultural change. In her preemigration life, Aura manifests the transcultural impulse to plunge into different cultural worlds. Initially, her transcendent urge emerges as nostalgia for unspecific, exotic landscapes and eventually as a firm intention to relocate to the United States. Later on, her academic background in English philology enlarges Aura's perspective, acquainting her with coordinates of the American culture. Aura's childhood involves a close contact with her paternal grandparents, whose marriage offers a precious example of communication across cultural differences. Her grandmother, Irma Balint, also known as Buni (the Romanian equivalent for Granny), is of Hungarian origin and her grandfather, Ioan Imbăruș, is of Romanian descent. Despite his family's prejudices towards Hungarians, the Romanian man eventually marries Irma and they have a happy life together. The spouses' ability to live in harmony notwithstanding their ethnic differences illustrates the transcultural possibility to reach agreement across cultural borders:

I remembered Buni and Grandpa together, always calling each other 'dear.' She spoke fluent Hungarian, German, Russian and Romanian. Grandpa spoke primarily Romanian, but he learned basic Hungarian for Buni. She spoke to my grandpa in Hungarian and German, and Grandpa responded in Hungarian or Romanian. (Imbăruș 45)

Buni's multicultural background and her ability to cohabit with cultural others paint her as a carrier of transcultural ideals. Her grandparents' cultural profile foregrounds Aura's diverse cultural inheritance that eases her transition to America. As well as Gogol's, Aura's capacity for transformation along transcultural lines appears as a continuation of her pre-emigration outlook, developed within her family. However, she is also different from Gogol, whose parents are predominantly conservative, striving to preserve their Bengali traditions after emigration. Despite Ashoke's transcendent urge to explore the universe of Russian literature, neither he nor Ashima insists that their children transgress their Bengali roots. Part of the explanation resides in the fact that Lahiri usually defines children's education as a prerogative of the wives, who are more attached to Bengali traditions than their husbands. Given the fact that Gogol's and 
Aura's examples illustrate the evolution of immigrants coming from different cultures and belonging to different generations, their paths to transcultural redefinition do not follow the same trajectory. An important dissimilarity is that Aura's pre-emigration outlook is more imbued with the values of cultural plurality than Gogol's background. Aura's relocation to America appears as a continuation of her pre-emigration transcultural mindset that enables her to blend different cultural models.

\section{Leaving Roots Behind}

A significant part of Aura's immigration experience involves her euphoric adherence to American ideals of individual success as material accumulation. As a newly arrived immigrant, Aura perceives America by opposition with her Romanian background, which indicates the mental border she maintains between the two cultures:

People strode around confidently, no furtive slinking or trudging along with stooped shoulders. What an astonishing difference from what we had been used to all our lives: where our fellow Romanians, inured to the harsh conditions of life under Communism, wore ever-present and deeply carved worry lines on their faces, fearing that someone, anyone, might report you for whatever the reason, and punishment was sure to follow. Here everyone seemed light-hearted, a good-natured demeanor flickered in their eyes. (Imbăruș 196, my emphasis)

Aura's dual perception of cultures configures Romania and America as sets of opposite values. America embodies freedom, relaxation and confidence, while Romania is associated with a space of communist oppression defined by fear, depression and paranoia. Aura's life in communist Romania made her familiar with the surveillance procedures of Ceauşescu's dictatorship that established a regime of terror in the country. This monitoring body, known as the Department of State Security (DSS) or Securitate, was established in 1948, following the model of the NKDV, the Soviet surveillance mechanism. The main task of Romania's Securitate was to identify, punish and/or remove all opponents of the communist regime that were considered enemies of the state (Duque, The View East, n.p.). Given the combination of coercion, 
surveillance and terror maintained with the help of the Secret Police, Romania's case was considered unique in Eastern Europe, as the regime met with little public or political opposition. Any attempt of revolt was severely punished either by long term imprisonment, assault or imposed exile (Duque, The View East, n.p.). Obviously marked by this oppressive context, Aura regards her relocation to America as a possibility to transgress restrictions of this kind. More specifically, America is perceived as a world that seems to fill in the gaps of Aura's Romanian past by offering priceless freedom. Given this state of things, Aura comes to define her sites of departure and arrival as signifiers of antipodal values. As an early immigrant, Aura displays a separatist conception of cultures that considers difference and not sameness, as an important criterion of definition. In this respect, she is similar to Gogol, given that he initially perceives the Bengali and American traditions as incompatible facets of his identity.

Another similarity between Aura and Gogol is their involvement in patterns of transnational mobility that renders them transmigrants, who maintain connections with their native cultural cores. However, Aura's transnational regime is different from Gogol's, as the frequency of her trips to Romania is higher than Gogol's family visits to India. In her case, the repeated journeys to Romania function as cultural barometers that indicate the degree of Aura's adjustment to the American culture. More specifically, Aura's reconnection with Sibiu at different time intervals helps her assess the (faulty and beneficial) directions of Romania's sociopolitical transformations. By expressing her own position towards Romania's evolution, Aura is able to clarify the development of her own post-migration loyalties. In some cases, her return journeys reveal the surge of Americanisation in Aura's cultural profile. In other instances, her temporary homecoming makes Aura's aware of her denial of roots that triggers her desire to reconstruct the bond with her ancestors' culture. The diverse effects of Aura's different return journeys are discussed in more details throughout this section. The following paragraph examines the manner in which Aura's reinsertion into her native space reflects the strengthening of her American allegiance. Aura's first visit back to Romania is motivated by her educational plans which involve her starting 
a PhD at Lucian Blaga University of Sibiu. Although brief, this trip makes Aura evaluate the configuration of her cultural loyalties. This temporary return journey helps Aura realise that she has transferred her home allegiance to LA, in the short interval following her departure from Romania: "Despite the Revolution, Romanian society was still rigid and monotone compared to America. I could never live in Romania again, not for any length of time. At least, this was my feeling at the time ... I loved LA. I had no doubts this was my home" (Imbăruș 209). Aura's thoughts illustrate her fast adjustment to America which is a result of her perceived compatibility with the American values. I consider that her feeling of belonging to the American space is also a consequence of her transcendent cultural outlook, shaped before her emigration. Aura's exposure to the American canvas helps her fashion her version of success in terms of the capacity to purchase and enjoy exclusivist brands. Her access to the American world of plenty seems to cancel the restrictions of her previous life in communist scarcity:

We traveled and bought designer clothes, another BMW - a Z 4 - and a Hummer, and later an RV. My American Dream was materializing. I bought a US flag and proudly put it up. No more dark nights in bleak and unheated spaces, no more lukewarm water and rationed food. No more nightmares about a government listening to my conversations and opening up my mail. I was now truly an American citizen. (Imbăruș 229-30)

Aura's steadfast pursuit of her consumerist ideals appears as a consequence of her communist background of destitution and restrictions. During the last decade of Ceauşescu's dictatorship, the Romanian population was confronted with extreme levels of poverty. The communist dictator was keen on paying the state's foreign debt in order to acquire an independent position that would enable him to ignore the claim on human rights made by Romania's trading partners. As a result, common people had to face food and electricity shortages, waiting in long lines for basic items (Livezeanu 2007). Aura seems particularly affected by this type of deprivation experienced in most of her pre-emigration life. Hence, Aura equates Americanisation with a long chain of acquisitions, meant to erase the shortages of her past. Her struggle to fulfil the American ideal of prosperity and freedom acquires huge proportions, as she becomes 
addicted to American standards of consumption. Aura's relation with her Romanian cultural core is influenced by her adherence to the American ideals of self-reliance and accumulation. In her effort to align with these standards of achievement, Aura deliberately neglects her contact with the source culture, perceived as an obstacle to her Americanisation: "feeling like I wanted to leave Romania behind, I'd actually distanced myself from my countrymen as much as I could" (Imbăruș 250). Aura's desire to embrace forces of cultural difference resembles Gogol's initial urge to shun elements of his Bengali identity. As a teenager, Gogol hates going to Bengali classes and resents the family's visits to Calcutta. Similarly, he is unwilling to follow a carrier embraced by most of the Bengalis in America (lawyers, doctors, engineers). The character's predicament is illustrated by the concept of American born confused/conflicted deshi (ABCD) commented at a panel discussion about Indian novels in English. The connotation of marginality invoked in the discussion reminds Gogol of a "medical condition," therefore a negative experience (Lahiri 118). This association reveals Gogol's rejection of his ethnic origins that mark him as different from mainstream Americans. However, Aura's relation with her Romanian background does not acquire the resentment accumulated by Gogol. His different approach to identity can be explained by the fact that Gogol's birth in America creates a much bigger gap between him and his parents' values. By contrast, Aura arrives in America in her adulthood and out of her own will, and these elements increase her chances of adaptation. While she does not attempt to suppress her Romanian self as Gogol does with his Bengali inheritance, Aura overlooks the importance of her native background for maintaining a whole sense of herself. At the same time, her accelerated mobility between Romania and America prevents her from forgetting the coordinates of her Romanian profile.

\section{Roots and Routes: Overlapping Dimensions}

On another trip to Romania, Aura spends an entire summer in Sibiu where she gets her PhD degree. This is a moment of personal triumph, an illustration of her ambition and ability to handle a transnational life. However, her repeated travel between America and Romania, without her 
husband, gradually marks a deterioration of their relationship. Her focus on career development leaves Aura no time for sharing her achievements with Michael. Eventually, Aura becomes aware of the emotional costs of her obstinate adherence to American norms of accomplishment. Her reconnection with Sibiu offers the necessary interval to process the consequences of her Americanisation in consumerist terms:

I became an AI-and it didn't stand for Aura Imbăruş. It stood for Artificial Intelligence, Artifice Image, the Appearance of Invincibility, Alienated Identity. All of the above. My addiction to things, which had been growing unnoticed for years, became overwhelming . . . I needed piles of new things to feel welcome in my hated home and worthy of being acknowledged by others

I,I,I

I was the navel of the universe, a confirmed solipsist. (Imbăruș 251)

Aura's sense of identity seems conditioned by her capacity to accumulate more and more goods. Her purchasing addiction may be interpreted as a strategy of sheltering herself by means of material possessions, meant to consolidate Aura's newly born American individuality. Absorbed by her ambition, Aura does not assess her profound transformation that triggers her separation from Michael. After they agree to divorce, Aura realizes that she needs to examine the effects of her obsessive search for material success. Entangled in her growing individualism, Aura needs to reconnect with other sources of meaning that might save her from the vortex of excessive consumption: "Clearly I needed to get back to things that brought me joy, peace, and purpose" (Imbăruș 252). Determined to change the hectic rhythm of her life, Aura needs to reconnect with her Romanian side and starts joining the monthly meetings of the Romanian American Professional Network (RAPN). Thus, when Aura feels lost amidst her consumerist fantasies, she finds "comforting solace" (Imbăruș 250) in the familiar presence of the Romanian community in California. Interestingly, both Aura and Gogol need to reconnect with their nonAmerican side in moments of personal distress, namely the loss of a dear one, either by divorce (Aura) or death (Gogol). After Ashoke's disappearance, Gogol realises that certain Bengali traditions, i.e. the mourning rituals performed for his father, are the only elements of support 
in times of suffering. His former indifference to these customs is superseded by a sense of belonging, induced by his ability to share them with his mother and sister.

Similarly, Aura's need to reconnect with her homeland by means of physical travel has to be understood in the context of this personal crisis that triggers a revaluation of her connection with her roots. One of her visits back home may be interpreted as a symbol of personal revival that coincides with a perceived "rebirth" (Imbăruș 253) of Romanian society. Aura is surprised by the transformation of her native city, temporarily selected as the cultural capital of Europe. She is impressed by its restoration, appreciating its successful blend of old traditions and new influences. The positive changes of Sibiu infuse Aura with optimism, making her feel proud of her Romanian inheritance: "Romanians had persevered after all. They had rebuilt their museums, reerected their monuments, sponsored and hosted artistic and cultural events and aimed at restoring the history and culture of a proud people" (Imbăruș 253). I interpret the perceived metamorphosis of the Romanian space as an echo of Aura's own attempts to redefine herself along less individualist lines. The fact that her visit back home is no longer motivated by professional objectives signals a shift from a success-oriented life to a more tranquil rhythm. Perhaps the most important element of this temporary return is the time Aura spends by herself, reflecting upon her relation with her Romanian side: "I didn't even realize how much I had missed being with my family, here in the old routine..." (Imbăruş 254). Analyzed through the perspective of transnational migration, this visit to Romania signals the gradual reconfiguration of Aura's loyalties. The days spent in her native city remind Aura of the importance of her roots and the family values that she has neglected in her race of success. As well as Gogol, Aura realizes that her desire for Americanisation has triggered the suppression of her source culture: "Walled off by responsibilities and wealth and material things, I had lost track of myself and my connections to my husband, my family, my community, my history" (Imbăruș 282). Aura's ambition, energy and determination have turned her into a victim of her own dreams. Focused on accelerated accumulation and consumption she has failed to maintain all her cultural facets interconnected. Confronted with 
feelings of fragmentation and loss, Aura realises that her happiness is conditioned by her ability to blend her Romanian and American experiences. Equipped with this new understanding, Aura reconnects with her former husband, reconfiguring a balanced sense of identity: "I've finally found true meaning again ... I had been so set on blocking out our past and conquering the American Dream - and I didn't even know what it really was. I feel like Transylvania feeds my roots, but I define myself as an American of Romanian descent - that's who I am" (Imbăruș 287).

Aura's new perspective makes room for her involvement in the activities of the Romanian community, where she finds a real self of purpose. Her need to consider her Romanian roots as an important part of her immigrant condition illustrates the enduring relevance of cultural loyalties and national belonging. These coordinates function as valid identity references paralleled by the fluidity of borders that seem to undermine the individuals' need to feel anchored. Aura's impulse to reconnect with the Romanian community in California illustrates the need to alleviate the alienating effects of extreme individualism, motivated by professional development and financial success: "No possession can ever have the lasting power to satiate the deeper hunger and longing within me: no, that requires the people in our life who love us and root for us and make us better human beings than we would have been without them" (Imbăruș 289, my emphasis). Human bonds and emotional support seem more important to Aura than the individualist race for material accumulation. Aura's longing for rootedness illustrates the importance of stable references in the shaping of transmigrant identity. Although her regime of transnational mobility seems to diminish the relevance of settlement and community bonds, Aura needs to manage her multifaceted self by reconnecting with her Romanian legacy. Aura's involvement in a non-profit organization for Romanian immigrant support illustrates her decision to redefine herself along transcultural lines. More specifically, Aura's recipe for immigrant success presupposes an integration of American norms into the Romanian background: "I decided RAPN could help Romanian immigrants like us adjust to life in the United States without them feeling that they have to give up their identity. . We think showing pride in our culture helps newer immigrants feel secure - and 
proud" (Imbăruș 287, my emphasis). Aura's commitment to the preserving of Romanian values illustrates her new conception of immigrant survival, born out of her initial failed approach to cultural transformation. Her intention to support other Romanian immigrants expresses Aura's desire to share the lesson she has learned with other fellow Romanians. Accordingly, the successful integration of Romanian immigrants entails their ability to engage in creative pluralism, by accommodating their values with American values and norms. Moreover, immigrant dignity is conditioned by their respect for their cultural inheritance that has to remain a significant part of their American lives.

\section{Conclusions}

This paper represents an attempt to sketch a comparative framework for analysing narratives of transcultural change in the context of transnational migration. The discussion has focused on different literary genres (a novel and a memoir), written by authors from different cultural spaces (Romania and India). Although these differences might discourage a comparative perspective, the present analysis has demonstrated that processes of transcultural redefinition operated by Indian and Romanian transmigrants do exhibit similar patterns. A significant similarity is represented by Gogol's and Aura's transcendent urge that motivates their desire to take over different cultural values and enrich their native cultural cores, perceived as incomplete systems. Interestingly, this transgressive outlook appears to have been shaped in the countries of origin, before the migration started. In Gogol's case, this transcendent disposition is configured as a male family trait, passed on from his grandfather to his father and finally to him. In an almost similar fashion, Aura has witnessed the effects of cultural transgression in her own multicultural family. This early acquaintance with cultural difference helps her negotiate cultural plurality and eventually build a transcultural self by means of creative pluralism. Interestingly, both Aura and Gogol experience their path to transcultural transformation as a struggle between rejecting and accepting the forces of cultural sameness. More specifically, both of them seem more preoccupied with taking over different cultural values, rather than 
maintaining their native cultural norms. At this point, I would argue that Gogol's struggle to repress his parents' (Bengali) background acquires larger proportions than Aura's. As a member of the second generation, Gogol experiences a larger distance from the Bengali traditions and a stronger impulse to contest them. By contrast, Aura is a first generation transmigrant, therefore her relation with her Romanian background is not as strongly mediated by temporal distance. Moreover, her regime of transnational relocation is more intense than Gogol's, which suggests that she can maintain stronger connections with her source culture. Despite these important differences, Gogol and Aura share a strong desire to adopt American values and somehow "correct" their cultural inheritance. They both focus on taking over elements of difference, overlooking the relevance of their native cultural cores. However, at some point both of them become aware of the necessity to acknowledge their ancestors' values and reconcile their native backgrounds with foreign cultural elements. Another similarity between Aura and Gogol is that they acknowledge the importance of their Romanian / Bengali roots in moments of family crises. As they are confronted with the possibility of losing a dear one, Aura and Gogol need to retrieve their cultural roots and blend their centripetal dimensions with American cultural values.

The analysis has suggested that similar mechanisms of transcultural redefinition may be upheld by transmigrants irrespective of their cultural backgrounds. Aura's and Gogol's evolution supports the idea that displaced individuals struggle to comprehend their cultural plurality, hesitating between rejecting and accepting their own specificity and the difference of others. However, once they are able to acknowledge the relevance of their roots, the transmigrants under discussion are able to adopt creative pluralism as a strategy of identity negotiation.

\section{Works Cited}

Basch, Linda, Glick Schiller, Nina and Christina Szanton Blanc. Nations Unbound - Transnational Projects - Postcolonial Predicaments and Deterritorialized Nation-States. London and New York: Routledge, 2003.

Berry, Ellen E. "Nomadic Desires and Transcultural Becomings." Transcultural Experiments Russian and American Models of Creative Communication. 
Ed. Berry, E. Ellen and N. Epstein, Mikhail.London and Berlin: Palgrave Macmillan, 1999. 121-40.

Caesar, Judith. "Gogol's Namesake: Identity and Relationships in Jhumpa Lahiri's The Namesake." Atenea 27.1 (2007): 103-19. Web. 10 Feb. 2009.

Crispin, Thurlow. "Transcultural Communication: A Treatise on trans." n.d, n.pag. Web. 12 February 2010.

Friedman, Natalie. "From Hybrids to Tourists: Children of Immigrants in Jhumpa Lahiri's The Namesake." Critique. 50.1 (2008):111-28. Web. 15 August 2011.

Epstein, Mikhail. After the Future: The Paradoxes of Postmodernism and Contemporary Russian Culture. Amherst: The University of Massachusetts Press, 1995.

Epstein, Mikhail. "From Culturology to Transculture." Transcultural Experiments Russian and American Models of Creative Communication. Ed. Berry E. Ellen and Epstein, Mikhail. London and Berlin: Palgrave Macmillan, 1999. 15-30.

Imbăruș, Aura. Out of the Transylvania Night. Bettie Youngs Book Publishers. 2010.

Lahiri, Jhumpa. The Namesake. London: Harper Perennial, 2004.

---. "Pulitzer Prize Winner Fiction." Interview by Farnsworth, Elizabeth. Online News Hour. July 16, 2000.Web. 20 May 2011.

---. "A Writer Free to Write All Day." Interview by Shankar, Radhika. Rediff India Abroad. August 23, 1999. Web. 25 January 2009.

---. "A Sense of Detail and a Sense of Order." Interview by Pandit, Lalita. Literary India Comparative Studies in Aesthetics Colonialism and Culture. Ed. Doniger, Wendy. State University of New York Press, Albany 1995.

---. "Jhumpa Lahiri on PEN's World Voices." Interview by Dottino, Suzanne. KGB Bar Lit Magazine. n.pag., n.d. Web. 1 June 2015.

Larsen, Jonas, Urry, John and Axhausen Kay. Mobilities, Networks, Geographies. Hampshire and Burlington: Ashgate, 2006.

Song, Min Hyoung. "The Children of 1965: Allegory, Postmodernism, and Jhumpa Lahiri's 'The Namesake." Twentieth-Century Literature 53.3 (2007): 345-70. Web. 1 Oct. 2011.

Stoican, A. Elena. "European Allegiances in the Context of South Asian American Transnational Migration." Shakespeare, Translation and the European Dimension. Ed. M.-S. Draga Alexandru, Nicolaescu Mădălina, Oana Alis Zaharia. Bucharest: ProUniversitaria, 2012. 241-258.

Stephen Vertovec. Transnationalism Key Ideas. London and New York: Routledge2009.

\section{Online Newspaper/Magazine Articles}

Duque, Nelson. The View East, Central and Eastern Europe, Past and Present. "Inside Ceauşescu's Romania: An Unquestionably Efficient Police State" nd. Web.11 July 2016.

Livezeanu, Irina. Making the History of 1989. "The Unique Experience of Romania”. University of Pittsburgh, Pennsylvania. Web.11 July 2016. 
Mitra, Sumit, Pais, J. Arthur. "Boston Brahmin.” India Today. 24 April 2000. Web. 9 June 2016.

"Visul American. Aura Imbăruş, profesor la Los Angeles." Revista Unica. 5 September 2013. Web. 22 April 2016. 